\title{
Inside Washington
}

\section{Christopher Wright \\ Assistant Director \\ ALA Washington Office}

On August 1 the American Library Association asked the Senate Subcommittee on Education to continue the library programs authorized in the soon-to-expire Higher Education Act of 1965 and to add a new section in the law providing special grants for research libraries to purchase resources.

The idea of a separate provision for research institutions had been triggered by a report from the prestigious Carnegie Council on Policy Studies in Higher Education released in the spring of 1975, which urged greater federal aid for graduate education and research and which specifically suggested some kind of help for large research libraries based on numbers of Ph.D. degrees granted. ALA suggested the new program might replace the language in Title II, Part C, of the law which authorized the National Program for Acquisitions and Cataloging now written into the Library of Congress budget authority.

While neither the Carnegie proposal nor ALA went into many specifics, ALA suggested that this new program should not be limited just to institutions granting Ph.D. degrees since this would exclude not only the great urban public libraries like Boston and New York which serve large numbers of scholars and authors but also the specialized independent research libraries such as the John Crerar and the Huntington.

The ALA statement as submitted to the Senate Subcommittee was supported by the Association of Research Libraries and was circulated within the library community for comments. However, only when the identical proposal was submitted six weeks later to the House Subcommittee on Postsecondary Education, which is also contemplating extension of the Higher Education Act, did anybody begin to take seriously the prospects for having a new Title II-C.

Then came the question of how you really define a research library. Who are we trying to help, after all? When it comes to the law, exactly what is a research library, and who is a researcher, and what are research materials?

The ALA proposal was an effort to solve one of the principal criticisms of the existing college library program and grew directly from a meeting of the ACRL committee on legislation in New York during the 1974 annual conference. At that meeting it became obvious that no one there was satisfied with the existing basic grant program. While the small colleges felt the $\$ 5,000$ grants were helpful both because they meant more money in the pot and because they required the college administration to maintain the library budget at a certain level, they felt the big libraries should be excluded because $\$ 5,000$ can have little impact on a $\$ 500,000$ book budget. The big research libraries, on the other hand, appeared willing to sacrifice the whole basic grant program in favor of a discretionary program in which they could compete for a really substantial amount of money for some special activity such as a bibliographic network or largescale collection development.

At the same time federal officials were begging Congress to end the college library program altogether, claiming it was a waste of funds to send out "dribs and drabs" of federal money to everybody including the Harvards and Yales.

Obviously, something needed to be done to narrow the scope of the basic grants and counter the dribs-and-drabs argument while giving the research institutions a realistic opportunity to use federal money for a national purpose.

In mid-July several things happened. First, the American Council on Education chose to make the Carnegie proposal part of its legislative program, suggesting its inclusion in the Part A, College Library Resources program. Second, the Library of Congress requested the NPAC language be removed from the Higher Education Act since this was creating confusion at budget time. Third, representatives from the country's major urban public libraries (many of them statistically research institutions) were urging that ALA find a solution to their economic plight, which appeared to be closer to that of academic libraries than to regular public libraries.

The result, after considerable discussion, was the ALA suggestion in the Senate statement. The idea was to reduce the numbers of institutions automatically eligible for $\$ 5,000$ grants (and thus counter a prime antilibrary argument by the administration) while opening up a new avenue of funding specifically for research institutions whose ranks were seen to include university libraries, the very biggest public 
library systems, and such places as the Folger and the Newberry.

The proposal has generated some interest on the part of Congress and it now becomes a matter of proposing statutory language that makes the right institutions eligible. Definitions have to be written with some eye to political realities and plain old good will. For instance, there are no ARL libraries in Montana, New Mexico, Arkansas, and Mississippi, which will dampen the interest of Senators Mansfield, Montoya, McClellan, and Stennis-all key members of the Senate appropriations committee. So perhaps eligibility has to include, let us say, the biggest academic library in any state or the largest public library. The difficulty is to avoid sounding elitist or pedantic while making the intent of the legislation perfectly clear.

In the coming months representatives of ACRL will be working with the ALA Washington Office and ARL to come up with wording that meets the needs of research libraries.

One thing is important to remember. Nobody gets a dime just for being eligible. But if more libraries are eligible, more people are out there lobbying for money for this program. The real need is to design a program that will actually get funded and do some good for the scholarships, authors, and students who use our research libraries.

\section{BOOKS FOR COLLEGE LIBRARIES}

\section{Second Edition}

The new edition of this essential publication for college libraries comprises six paperbound volumes:

Volume 1 hUMANITIES

2 LANGUAGE AND LITERATURE

3 HISTORY

4 SOCIAL SCIENCE

5 PSYCHOLOGY, SCIENCE, AND TECHNOLOGY

6 INDEX

The preparation of the Second Edition, a project of the Association of College and $\mathrm{Re}$ search Libraries, a division of ALA, was funded by the Council on Library Resources. The nearly 40,000 titles selected are considered to be the minimum essential for the four-year undergraduate library. Subject specialists evaluated the titles in the earlier edition and titles published between 1964 and 1972. ISBN 0-8389-0178-6 \$65.00

Order Department

AMERICAN LIBRARY ASSOCIATION

50 East Huron St., Chicago, IL 60611
The editors have received the following letter supporting the ACRL Board of Directors policy statement on the M.L.S. degree:

\section{Dear Editor:}

I fully endorse the decision of the ACRL Board of Directors to declare the master's degree in library science the appropriate terminal degree for professional librarians. Additional degrees in other subject matters may enhance the librarian's value in specialized fields, but unless we want to become bibliographic assistants to authorities in other fields we must assert our independence and strive for excellence in our own area. We should be proud to be generalists because we form the information link between the various disciplines and our task is to bring them together. We help the information seeker to formulate the questions to be answered and either supply the necessary information or show the paths to it regardless of the form in which the information may be recorded. We also facilitate contact between the information seekers and those knowledgeable in that field for discussion and answers. Often directional and routine and superficial reference questions would lead to deeper research and better understanding if they were handled by competent reference librarians instead of nonprofessional assistants. Academic libraries have never recognized limitations or classifications as finite and therefore have always paid attention to the needs for individual instruction. The drive of librarians for full faculty status should be based on the importance of librarians to academic development toward excellence at our institution and on the importance of our contribution to the intellectual development of each individual in our academic community who cares to take advantage of our services. Librarians have a unique opportunity to emphasize the interrelationship of the various disciplines and to act as catalysts for identification with our academic institutions, and thus become indispensable governance participants.

\author{
Sincerely, \\ Leo R. Rift \\ College Librarian \\ Ithaca College \\ Ithaca, New York
}

